\title{
STRATEGI PENINGKATAN KUALITAS BELANJA DAERAH PROVINSI BANTEN
}

\author{
Strategy for Improvement Local Expenditure Quality in Banten Province \\ Yuki Satria Putra', Bambang Juanda로 Ma`mun Sarma ${ }^{3}$ \\ ${ }_{1}$ Auditor Badan Pengawasan Keuangan dan Pembangunan (BPKP) RI. E-mail : uq_satria@yahoo.co.id \\ 2 Staff Pengajar Departemen Ilmu Ekonomi, Fakultas Ekonomi dan Manajemen, IPB. E-mail : \\ bbjuanda@yahoo.com \\ 3 Staff Pengajar Departemen Manajemen, Fakultas Ekonomi dan Manajemen, IPB. E-mail : \\ mamun_sarma@yahoo.com
}

\begin{abstract}
The study aims to formulate an appropriate strategy for the Government of Banten Province in improving the quality of local expenditure. The study is conducted on the expenditure quality in Banten and then, continued to formulate the appropriate strategy for it. There are 12 indicators expenditures which are used. Expenditure discipline of allocation, the accuracy of the target in distributing grant and social financial support, the accuracy of schedule in determining APBD, the accuracy of schedule in realizing revenue and expenditure, the effectiveness and efficiency of expenditure accountability, transparency of local government financial report and BPK opinion on it. Data collection is done by distributing questioners, document analysis, and interviews. The results show that expenditure had been disciplined priority program, the allocation of capital expenditure is still low, the allocation of personnel expenditure is good, the grant and the social financial support had not reached target yet, there was still APBD which was determined unpunctually, unpunctually expenditure realization. The expenditure was not effective and efficient, there was still unaccountable, accountability has been transparency and BPK opinions has not good. The strategy to be implemented for this case is the increasing commitment of all sides to increase the expenditure quality of Banten Province region.
\end{abstract}

Keywords: Strategy, Banten Province, Quality Of Spending, APBD

\begin{abstract}
ABSTRAK
Penelitian ini bertujuan untuk merumuskan strategi yang tepat bagi Pemerintah Provinsi Banten dalam meningkatkan kualitas belanja daerah. Kajian dilakukan terhadap kondisi kualitas belanja dan dilanjutkan dengan penyusunan strategi. Ada 12 Indikator kualitas belanja yaitu disiplin belanja terhadap program prioritas, ketepatan alokasi belanja modal dan belanja pegawai, ketepatan sasaran pemberian hibah dan bansos, waktu penetapan APBD, realisasi pendapatan dan belanja, efektifitas dan efisiens, akuntabilitas, transparansi dan opini BPK. Pengumpulan data dilakukan dengan penyebaran kuesioner, analisis dokumen dan wawancara. Hasil penelitian yaitu belanja sudah disiplin dengan program prioritas, alokasi belanja modal masih rendah, alokasi belanja pegawai sudah baik, hibah dan bansos belum tepat sasaran, APBD belum tepat waktu, realisasi pendapatan tepat waktu, realisasi belanja belum tepat waktu, belanja belum efisien dan efektif, belanja belum semua dapat pertanggungjawaban, pertanggungawaban sudah transparan dan opini BPK belum baik. Strategi untuk diimplementasikan yaitu peningkatan komitmen seluruh pihak dalam rangka peningkatan kualitas belanja daerah Provinsi Banten.
\end{abstract}

Kata Kunci : Strategi, Provinsi Banten, Kualitas Belanja, APBD

\section{PENDAHULUAN}

Kebijakan otonomi daerah pada tahun 2001, memberikan kewenangan yang besar pada Pemerintah Daerah untuk mengatur dan mengurus sendiri urusan pemerintahan dan kepentingan masyarakatnya sesuai dengan peraturan perundang-undangan.
Sebagai implikasi kebijakan otonomi daerah, pemerintah pusat terus berusaha meningkatkan alokasi dana transfer kepada pemerintah daerah untuk membiayai pembangunan daerah. Jumlah dana transfer kepada daerah tahun 2016 mencapai Rp 758,3 triliun atau $69,7 \%$ dari total APBD 
nasional dan meningkat sebesar $18 \%$ dari tahun sebeumnya yang hanya sebesar Rp 885,3 triliun (www.kemenkeu-djpk.go.id). Dana transfer yang diterima daerah dialokasikan dalam berbagai program dan kegiatan pembangunan daerah dalam dokumen

Kementerian Keuangan RI dalam kajiannya tentang spending performance (2014) menyatakan bahwa kualitas belanja daerah dan APBD selama ini dianggap masih lemah yang ditandai dengan adanya alokasi belanja tidak langsung yang selalu lebih besar dari belanja langsung, alokasi belanja modal yang rendah, penyerapan belanja daerah yang relatif rendah terutama terkait dengan belanja modal dan belanja barang yang terkait dengan public service delivery. Bappenas (2011;22) dalam kajiannya tentang kualitas belanja daerah menyebutkan bahwa kualitas belanja dan penganggaran merupakan bagaimana proses dan hasil perumusan APBD sesuai dengan nilai-nilai ekonomi, efisiensi, efektivitas, equity/keadilan, akuntabilitas, dan responsivitas. Juanda et al (2013;39) dalam kajiannya menyatakan bahwa belanja berkualitas adalah belanja yang dialokasikan berdasarkan prioritas pembangunan daerah dan dilakukan secara efisien dan efektif, tepat waktu dan alokasi, transparan dan akuntabel. Dalam kajiannya, Juanda et al mengatakan bahwa terdapat 5 variabel dan 12 indikator yang terkait dengan kualitas belanja daerah sebagaimana disajikan dalam gambar berikut.

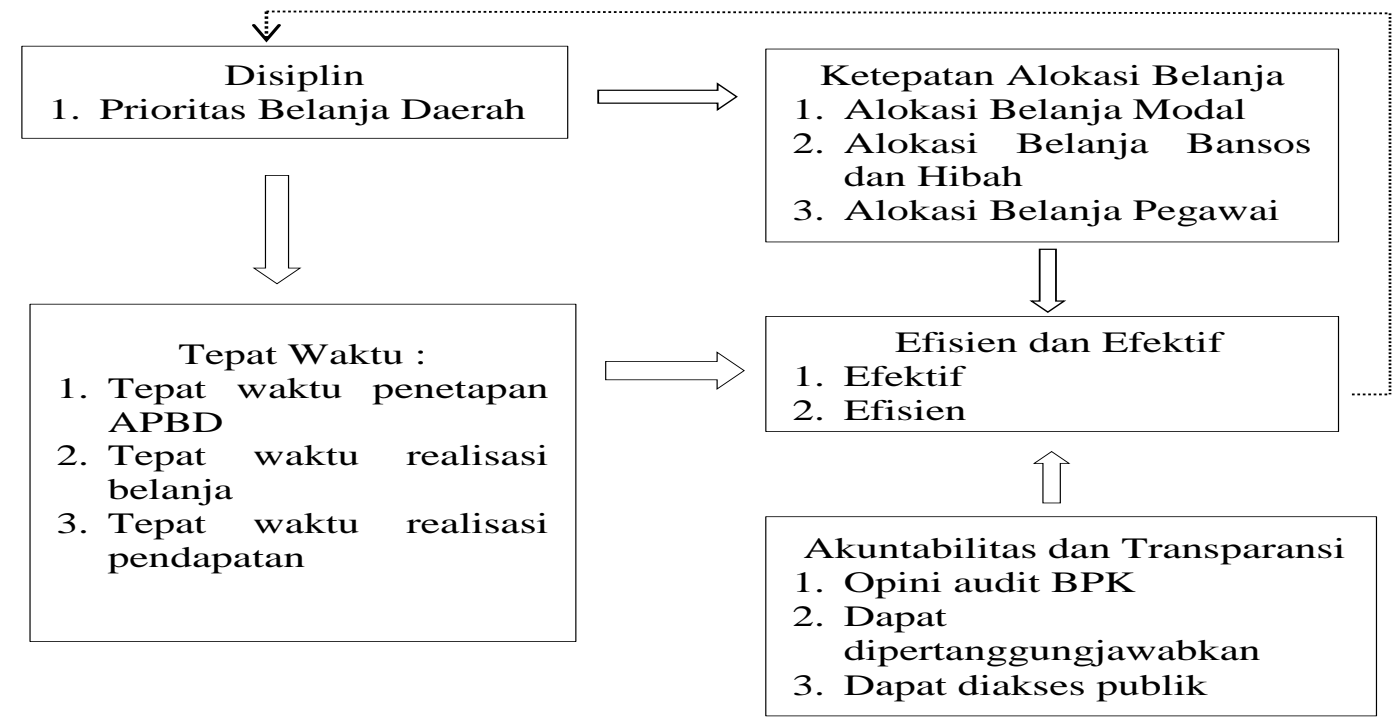

Sumber : Juanda et al, 2013

Gambar 1. Keterkaitan Atribut dan Indikator Kualitas Belanja Daerah

Keterkaitan antar atribut belanja tersebut dapat dijelaskan bahwa setiap perencanaan dan penganggaran atas sebuah program dan kegiatan akan bermuara pada keterbatasan anggaran. Keterbatasan anggaran memunculkan urutan pilihan atau prioritas. Belanja berkualitas akan menempatkan atribut prioritas untuk dilaksanakan dengan disiplin tinggi. Kedisiplinan yang tinggi terhadap prioritas akan menentukan ketepatan alokasi anggaran seperti yang ditunjukkan oleh indikator besaran alokasi belanja modal, alokasi belanja hibah dan bansos, serta belanja pegawai. Prioritas belanja yang telah ditentukan secara baik dan kemudian dianggarkan tidak akan berarti jika anggarannya (APBD) tidak disusun tepat waktu, demikian pula jika realisasi belanja maupun pendapatan tidak tepat waktu. Atribut ketepatan waktu merupakan hal yang tidak kalah penting dalam belanja yang berkualitas. Lebih jauh, belanja yang berkualitas dapat dipahami dengan jelas bahwa belanja tersebut memenuhi konsep ekonomi, efisien, dan efektif. Untuk itu 
atribut tersebut harus sejalan atau didukung dengan atribut ketepatan waktu dan ketepatan alokasi belanja. Selain itu tuntutan atas belanja pemerintah harus dikelola secara transparan dan akuntabel atas ekonomis, efisiensi dan efektivitas belanja yang dilakukan. Jadi atribut transparansi dan akuntabilitas dapat dipahami sebagai salah satu atribut pada kualitas belanja (Juanda et al, 2013).

Kementerian Keuangan dalam salah satu kajiannya tentang spending performance menemukan beberapa permasalahan terkait dengan kualitas belanja daerah Provinsi Banten pada tahun anggaran 2013. Permasalahan yang ditemukan antara lain 1) saat belanja pegawai dan barang dan jasa mengalami peningkatan alokasi, belanja modal mengalami penurunan alokasi; 2) belanja hibah merupakan belanja dengan alokasi terbesar dibanding belanja barang dan jasa dan belanja modal; 3) realisasi anggaran triwulanan Pemprov Banten dianggap tidak tepat waktu serta 4) penyerapan belanja modal sebagai belanja publik masih rendah dibandingkan dengan belanja lainnya. Dari hasil kajian tersebut dapat dikatakan bahwa kondisi tahun 2013 menunjukkan bahwa kualitas belanja daerah pada Provinsi Banten belum menunjukkan keberpihakan yang besar pada pelayanan publik.

Berkaitan dengan hal-hal yang dipaparkan di atas, maka penulis tertarik mengkaji bagaimana Strategi Pemerintah Provinsi Banten mengatasi permasalahan dalam pengelolaan belanja sehingga dapat meningkatkan kualitas belanja daerahnya. Sehubungan dengan hal tersebut maka kajian yang akan penulis lakukan ini memiliki tujuan sebagai berikut: 1) mendeskripsikan struktur dan perkembangan APBD Provinsi Banten; 2) menganalisis kondisi kualitas belanja daerah Provinsi Banten; 3) menyusun strategi yang tepat dalam upaya meningkatkan kualitas belanja dareah Pemerintah Provinsi Banten.

\section{METODE PENELITIAN}

\section{Lokasi Penelitian dan Sumber Data}

Penelitian dilakukan pada Pemerintah Daerah Provinsi Banten pada bulan Maret Mei 2017. SKPD sebagai obyek penelitian berjumlah 15 SKPD. Jenis data yang digunakan dalam penelitian ini terdiri dari data primer dan data sekunder. Data primer diperoleh dengan cara penyebaran kuesioner dan wawancara, data sekunder diperoleh dari studi pustaka/literatur/dokumen. Data sekunder menggunakan data periode RPMD 20122017.

\section{Teknik Pengolahan dan Analisis Data}

Penelitian dilakukan dengan menggunakan pendekatan kualitatif dan kuantitatif. Alat analisis yang digunakan dalam penelitian ini adalah modus, deskriptif, rasio, perkembangan dan konsistensi perencanaan (MKPP). Hasil dari kuesioner diterjemahkan secara bersamaan dengan hasil wawancara dan studi pustaka untuk mendapatkan pemahaman yang lebih luas dan sekaligus bisa menjalin interaksi data untuk memantapkan pembahasan dan pengambilan kesimpulan. Langkah selanjutnya adalah merumuskan strategi dengan menggunakan analisis SWOT dan QSPM.

\section{HASIL DAN PEMBAHASAN}

\section{Perkembangan APBD Provinsi Banten}

Struktur APBD Provinsi Banten terdiri dari Pendapatan Daerah, Belanja Daerah, Surplus (Defisit), Pembiayaan dan Silpa. APBD Provinsi Banten mengalami peningkatan dari tahun ke tahun baik anggaran pendapatan maupun anggaran belanja daerah. Selama periode 2013-2016, peningkatan anggaran pendapatan daerah tertinggi terjadi pada tahun 2017 yang mencapai $\mathrm{Rp} 1,316$ triliun atau sebesar $15,35 \%$, dan yang terendah terjadi pada tahun 2014 yaitu sebesar Rp 569 milyar atau sebesar 9,07\%. Secara rata-rata pada periode tahun 2013-2017 peningkatan 
pendapatan daerah mencapai Rp 880 milyar atau sebesar $11,8 \%$.

Peningkatan alokasi belanja tertinggi dalam periode 2013-2017 terjadi pada tahun 2014 mencapai Rp 1,466 triliun atau sebesar $22,88 \%$, terendah terjadi pada tahun 2016 yang hanya sebesar Rp 25 Milyar atau sebesar $0,27 \%$ dan secara rata- rata mencapai 13,06\% atau sebesar Rp 986 milyar. Kenaikan belanja daerah yang hanya sebesar Rp 25 milyar pada tahun 2016 disebabkan Silpa tahun sebelumnya mengalami penurunan yang cukup besar. Berikut Gambar 2 perkembangan anggaran pendapatan dan belanja Provinsi Banten.

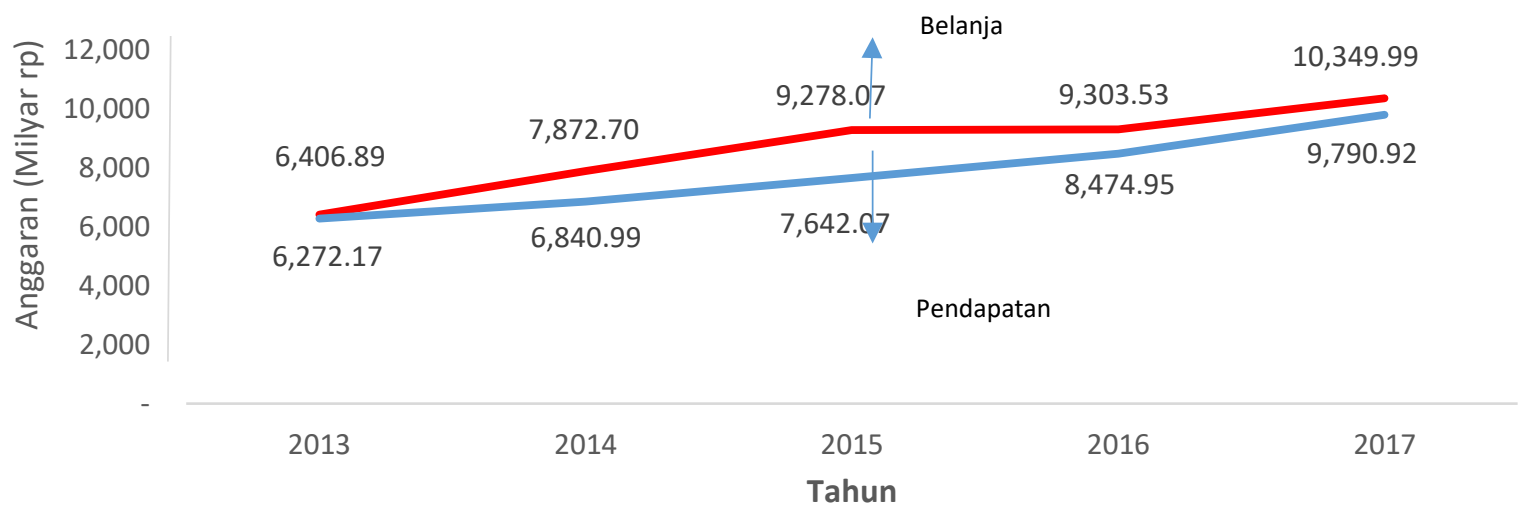

Sumber : APBD Provinsi Banten (2013-2017)

Gambar 2. Perkembangan anggaran pendapatan dan belanja Provinsi Banten

Realisasi pendapatan daerah milyar atau 96\% dari anggaran sebesar Rp. Provinsi Banten cukup tinggi dengan 7.642 milyar. Secara rata-rata periode 2013persentase capaian tertinggi pada tahun 2016 realisasi pendapatan daerah mencapai 2014 sebesar Rp 7.068 milyar atau 103\% 100,17\%. Berikut Gambar 3 realisasi dari anggaran sebesar Rp 6.841 milyar dan terendah pada tahun 2015 sebesar Rp 7.328

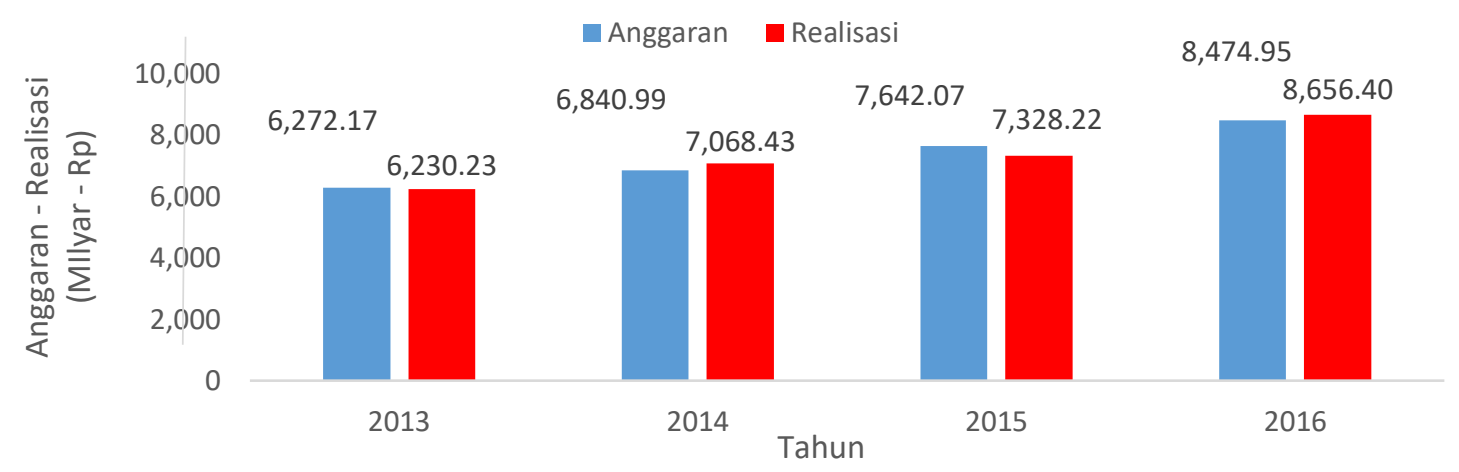

Sumber : LKPD Provinsi Banten (2013-2016)

Gambar 3. Anggaran dan realisasi pendapatan daerah Provinsi Banten

Realisasi belanja tahun 2013 mencapai Rp 5.295 milyar dan pada tahun 2016 mencapai Rp 8.926 milyar. Dalam periode 2013-2016, kenaikan realisasi belanja daerah mencapai Rp 3.630 milyar atau $68 \%$. Berdasar kelompok belanja, ratarata realisasi belanja tidak langsung mencapai 95\% dibanding anggaran, lebih tinggi dari pada realisasi belanja langsung yang hanya sebesar $75 \%$. Belanja tidak langsung terdiri dari belanja pegawai, hibah, bansos, bantuan keuangan, bagi hasil dan belanja tidak terduga. Belanja langsung terdiri dari belanja pegawai, barang jasa dan 
modal. Dari ketiga jenis belanja langsung tersebut, realisasi belanja paling rendah adalah belanja modal. Secara rata-rata dalam periode 2013-2016 realisasi belanja pegawai mencapai $89 \%$, belanja barang dan jasa $86 \%$ dan belanja modal $64 \%$. Berikut Gambar 4 realisasi belanja daerah Provinsi Banten.

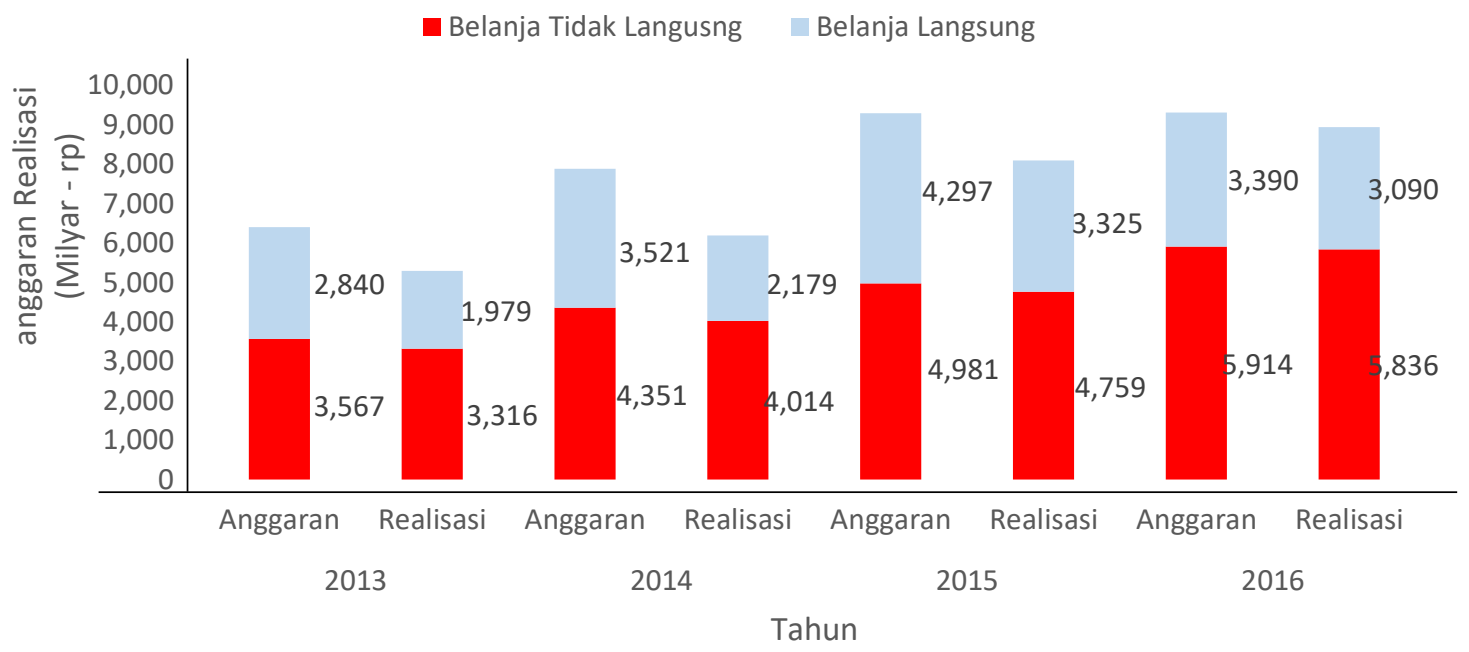

Sumber : LKPD Provinsi Banten (2013-2016)

Gambar 4 Anggaran dan realisasi belanja

\section{Kualitas Belanja Daerah Provinsi Banten}

Hasil pengolahan data kuesioner, mayoritas respnden memberikan jawaban bahwa kualitas belanja daerah Provinsi Banten dalam kinerja 3 (baik/setuju) dengan pernyataan yang ditanyakan untuk
11 indikator. Untuk indikator belanja daerah tepat waktu mayoritas responden menyatakan bahwa belanja daerah belum tepat waktu atau dalam kinerja 2 (kurang baik/kurang setuju) dengan pernyataan yang ditanyakan. Berikut hasil kuesioner kualitas belanja daerah.

Tabel 1. Hasil Kuesioner

\begin{tabular}{|c|c|c|c|c|c|c|c|}
\hline \multirow{2}{*}{ No } & \multirow{2}{*}{ Indikator } & \multicolumn{4}{|c|}{ Kinerja } & \multirow{2}{*}{ Jumlah } & \multirow{2}{*}{ Modus } \\
\hline & & 4 & 3 & 2 & 1 & & \\
\hline 1 & Program Prioritas & 3 & 10 & 0 & 0 & 13 & 3 \\
\hline 2 & Belanja Bantuan Tepat Sasaran & 2 & 8 & 2 & 0 & 12 & 3 \\
\hline 3 & Belanja Pegawai < dari $50 \%$ & 4 & 5 & 3 & 0 & 12 & 3 \\
\hline 4 & Belanja Modal Lebih 30\% & 2 & 7 & 3 & 0 & 12 & 3 \\
\hline 5 & APBD Tepat Waktu & 2 & 9 & 2 & 0 & 13 & 3 \\
\hline 6 & Pendapatan Tepat Waktu & 1 & 9 & 3 & 0 & 13 & 3 \\
\hline 7 & Belanja Daerah Tepat Waktu & 0 & 5 & 6 & 0 & 11 & 2 \\
\hline 8 & Belanja Daerah Efektif & 3 & 6 & 3 & 0 & 12 & 3 \\
\hline 9 & Belanja Daerah Efisien & 1 & 9 & 3 & 0 & 13 & 3 \\
\hline 10 & Dapat dipertanggungjawabkan & 3 & 9 & 1 & 0 & 13 & 3 \\
\hline 11 & Transparan & 3 & 8 & 2 & 0 & 13 & 3 \\
\hline 12 & Opini Audit & 3 & 8 & 2 & 0 & 13 & 3 \\
\hline
\end{tabular}

Sumber : Data diolah (2017) 


\section{Disiplin Belanja Terhadap Program Prioritas Pembangunan}

Analisis terhadap dokumen perencanan dan penganggaran dilakukan dengan menggunakan Matriks Konsistensi Perencanaan dan Penganggaran (MKPP) (Meldayeni, 2011). Analisis ini bertujuan untuk melihat konsistensi program prioritas mulai dari RPJMD hingga APBD. Pemerintah Priovinsi Banten memiliki 78 program prioritas selama periode RPMD 2012-2017. Hasil analisis program prioritas Pemerintah Provinsi Banten disajikan pada Tabel 2.

Tabel 2. Matriks Konsistensi Perencanaan dan Penganggaran

\begin{tabular}{|c|c|c|c|c|c|c|c|c|c|c|}
\hline \multirow{2}{*}{ Dokumen Program } & \multicolumn{2}{|c|}{2013} & \multicolumn{2}{|c|}{2014} & \multicolumn{2}{|c|}{2015} & \multicolumn{2}{|c|}{2016} & \multicolumn{2}{|c|}{2017} \\
\hline & Ya & Tdk & Ya & $\mathrm{Tdk}$ & $\mathrm{Ya}$ & Tdk & Ya & Tdk & $\mathrm{Ya}$ & $\mathrm{Tdk}$ \\
\hline RPJMD-RKPD & 78 & & 78 & & 78 & & 78 & & 73 & 5 \\
\hline RKPD-KUA PPAS & 78 & & 78 & & 78 & & 78 & & 73 & 5 \\
\hline $\begin{array}{l}\text { KUA-PPAS- } \\
\text { RAPERDA }\end{array}$ & 78 & & 78 & & 78 & & 78 & & 73 & 5 \\
\hline RAPERDA-APBD & 78 & & 78 & & 78 & & 78 & & 73 & 5 \\
\hline Konsistensi & $100 \%$ & & $100 \%$ & & $100 \%$ & & $100 \%$ & & 93,599 & \\
\hline
\end{tabular}

Sumber : Dokumen Perencanaan Provinsi Banten 2013-2017, diolah.

Dari hasil analisis diperoleh tingkat konsistensi program prioritas RPJMD 2012-2017 sebesar 98,72\% dan masuk dalam kategori sangat baik. Program prioritas yang terdapat dalam RPJMD konsisten dengan program prioritas yang terdapat dalam RKPD hingga APBD tahun 2013 sampai dengan tahun 2016. Pada tahun anggaran 2017 terdapat 5 program prioritas Dinas Pendidikan yang tidak masuk dalam RKPD, KUA-PPAS, Raperda APBD dan APBD yaitu Program Pendidikan Anak Usia Dini (PAUD), Pendidikan dasar wajib belajar 9 tahun, Peningkatan mutu, Kesejahteraan dan perlindungan pendidikan dan tenaga kependidikan, Pendidikan tinggi dan Pendidikan non formal dan informal (PNFI). Tidak dimasukkannya program prioritas pada dokumen perencanaan dan penganggaran tahun 2017 disebabkan adanya perubahan kewenangan Pemprov
Banten dalam bidang pendidikan serta pengalokasian belanja program tersebut kepada belanja gaji dan tunjangan tenaga pendidik sekolah menengah yang beralih ke provinsi.

\section{Ketepatan Alokasi Belanja Daerah}

Perkembangan alokasi belanja modal Provinsi Banten periode 2013-2017 cenderung mengalami penurunan. Pada tahun 2013, alokasi belanja modal sebesar $23 \%$ atau $\mathrm{Rp} 1,5$ triliun dibandingkan APBD sebesar Rp 6,4 triliun. Pada tahun 2014 dan 2015, secara nilai rupiah alokasi belanja modal mengalami peningkatan namun secara persentase mengalami penurunan. Tahun 2016, alokasi belanja modal mengalami penurunan baik secara persentase maupun secara nilai rupiah. Berikut disajikan perkembangan alokasi belanja modal periode 2013-2017

Tabel 3. Alokasi belanja modal

\begin{tabular}{crrrrrr}
\hline $\begin{array}{c}\text { Anggaran } \\
\text { Belanja Modal }\end{array}$ & $\mathbf{2 0 1 3}$ & $\mathbf{2 0 1 4}$ & $\mathbf{2 0 1 5}$ & $\mathbf{2 0 1 6}$ & $\mathbf{2 0 1 7}$ & Rata-rata \\
\hline Rupiah-Milyar & $1.520,38$ & $1.739,63$ & $1.937,45$ & $1.486,67$ & $1.515,65$ & $1.639,96$ \\
\hline Persentase (\%) & 23,73 & 22,10 & 20,88 & 15,98 & 14,64 & 19,47 \\
\hline
\end{tabular}

Sumber : APBD 2013-2017, diolah. 
Peraturan Presiden No 5 tahun 2010 yang mengamanatkan bahwa dalam APBD daerah, terhitung mulai tahun 2010 alokasi belanja modal mencapai $26 \%$ dan meningkat setiap tahun sebesar $1 \%$ hingga mencapai $30 \%$ pada tahun 2014. Permendagri No 27 Tahun 2013 tentang Pedoman Penyusunan APBD Tahun Anggaran 2014 telah menginstruksikan kepada Pemerintah Daerah untuk mengalokasikan sekurang-kurang 30\% dari APBD diperuntukan untuk belanja Modal. Dari alokasi belanja belanja modal periode 2013-2017 Pemprov Banten belum pernah mengalokasikan anggaran belanja modal mencapai $30 \%$.

Menurunnya alokasi belanja modal Pemerintah Provinsi Banten bertolak belakang dengan peningkatan alokasi belanja dalam APBD Provinsi Banten. Dalam periode yang sama, pertumbuhan belanja Provinsi Banten dari sisi jumlah rupiah mencapai $13,06 \%$ jauh di atas pertumbuhan belanja modal yang hanya mencapai $4 \%$, sedangkan jika dilihat pertumbuhan dari sisi persentase, belanja modal mengalami pertumbuhan minus hingga $-2,27 \%$. Salah satu anggota TAPD Pemprov Banten yang diwawancarai berpendapat bahwa peran Pemerintah
Provinsi berbeda dengan Kabupaten Kota, kegiatan Pemerintah Provinsi lebih bersifat koordinatif dan supervisi terhadap pembangunan Kabupaten Kota. Jika terjadi gap fiskal di Kabupaten Kota yang tidak bisa difasilitasi oleh APBD Kabupaten dan Kota, Provinsi memberikan bantuan keuangan untuk digunakan pembangunan infrastrutkur.

Anggaran belanja pegawai Pemerintah Provinsi Banten periode 20132017 secara rata-rata berkisar sebesar Rp 943,11 milyar atau sebesar 10,7\% dari total belanja. Pada tahun 2017 anggaran belanja pegawai mencapai $17,41 \%$ dari total belanja. Anggaran tahun 2017 mengalami kenaikan yang cukup tinggi dari tahun sebelumnya yang berkisar $8,09 \%$ dari total belanja. Kenaikan alokasi belanja pegawai yang cukup tinggi ini dikarenakan perubahan kebijakan Pemprov Banten terkait dengan tunjangan daerah PNS Provinsi Banten. Alokasi belanja pegawai yang mencapai $17,41 \%$ masih dianggap ideal karena masih dibawah 50\% APBD dan dibawah belanja pegawai secara nasional yang mencapai $48,04 \%$. Berikut Gambar 5 alokasi belanja pegawai Pemprov Banten.

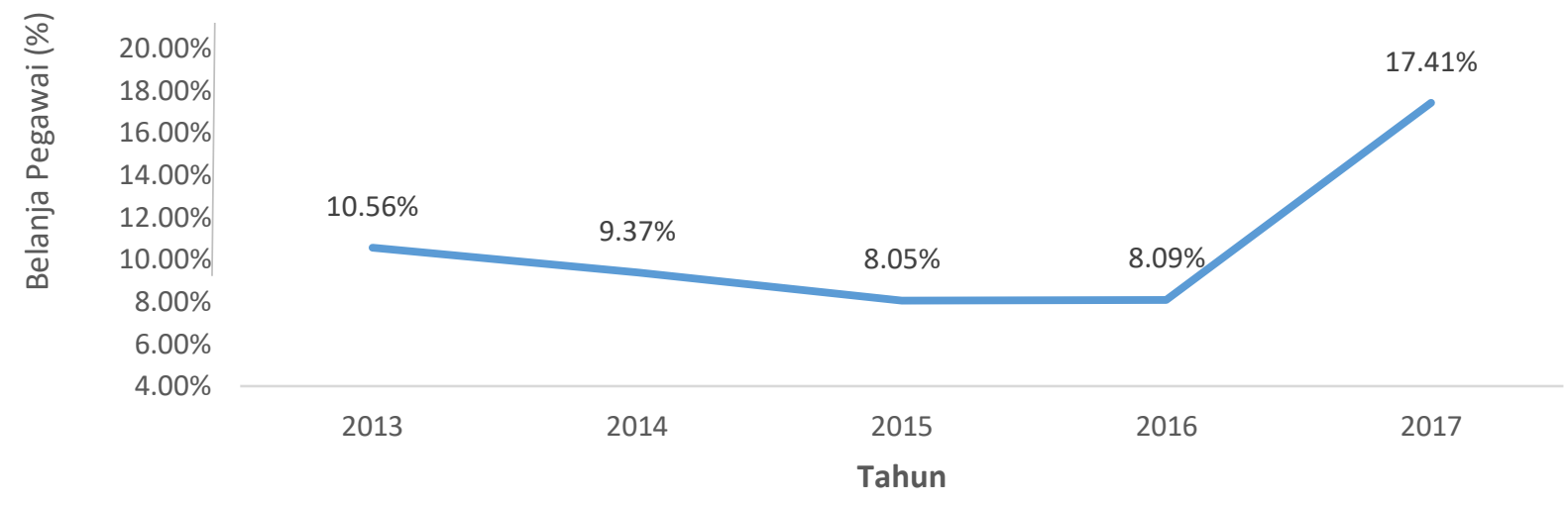

Sumber : APBD 2013-2017, diolah

Gambar 5 Alokasi belanja pegawai Pemprov Banten

Alokasi anggaran belanja hibah dan bansos Provinsi Banten periode 2013-2017 secara rata-rata mencapai Rp 1.9 triliun atau sekitar $22,82 \%$ dari total rata-rata anggaran belanja daerah sebesar Rp 8,6 triliun. Jika dibandingkan dengan alokasi belanja modal pada periode yang sama, alokasi belanja hibah dan bansos lebih tinggi dari alokasi 
belanja modal yang hanya sebesar $19,47 \%$ dan belanja pegawai sebesar $10,7 \%$. Pada tahun 2017, alokasi anggaran hibah dan bansos mencapai Rp 2,5 triliun atau 24,3\% dari total anggaran. Alokasi terbesar dari belanja hibah dan bansos diperuntukkan untuk penggunaan dana BOS (Biaya Operasioanl Sekolah) se Provinsi Banten.

Dalam peraturan Gubernur No 56 tahun 2015 dan perubahnnya disebutkan bahwa pemberian hibah ditujukan untuk menunjang pencapaian sasaran program dan kegiatan Pemerintah Daerah dengan memperhatikan asas keadilan, kepatutan, rasionalitas dan manfaat untuk masyarakat. Berdasar hasil kajian, secara umum pemberian hibah dan bansos belum tepat sasaran. Hal ini karena pemberian hibah dan bansos belum didukung dengan evaluasi atas sasaran capain program bidang terkait. Selain itu dalam laporan kinerja juga tidak terdapat capaian program kegiatan yang didukung oleh hibah dan bansos. Menurut anggota TAPD Pemprov Banten menyatakan bahwa pada umumnya pemberian hibah dan bansos tersebut tanpa melihat apakah hibah dan bansos tersebut mendukung pencapaian sasaran program dan kegiatan pemerintah dan ini merupakan kelemahan dalam pengendalian pemberian hibah dan bansos.

\section{Ketepatan Waktu APBD, Pendapatan dan Belanja}

Dalam penyusunan APBD periode 2013-2017, APBD tahun 2014 dan 2017 ditetapkan tidak tepat waktu, sementara APBD 2013, 2015 dan 2016 ditetapkan tepat waktu. APBD tahun 2017 tidak dapat ditetapkan tepat waktu karena adanya perubahan nama SKPD Provinsi Banten sehubungan dengan berlakunya UU No 23 Tahun 2014. Selain itu, adanya perubahan penggunaaan aplikasi penyusunan perencaan juga ikut menyebabkan keterlambatan pengesahan APBD tahun 2017.

Hasil kajian dokumen realisasi anggaran pendapatan per triwulan diketahui bahwa realisasi pendapatan daerah terendah dalam 1 triwulan terjadi pada triwulan I tahun 2013 sebesar 21,92\% dari anggaran dan realisasi tertinggi sebesar $27,72 \%$ pada triwulan IV tahun 2016. Secara rata-rata, realisasi pendapatan triwulan I berkisar sebesar 22,60\%, triwulan II $25,97 \%$, triwulan III $25,72 \%$ dan triwulan IV $25,89 \%$. Dengan rata-rata realisasi pendapatan berkisar antara $21,92 \%$ hingga $27,72 \%$ pertriwulan, jumlah ini cukup untuk memenuhi kebutuhan belanja triwulanan Pemerintah Provinsi Banten.

Dalam periode tahun 2013-2017 belanja daerah Provinsi Banten belum dapat direalisasikan secara tepat waktu. Realisasi belanja daerah secara triwulanan paling rendah terjadi pada triwulan I tahun 2014 sebesar $5,53 \%$ dan tertinggi terjadi pada triwulan IV tahun 2015 sebesar 42,42\%. Rata-rata dalam periode 2013-2017, triwulan I hanya mampu merealisasikan belanja sebesar $7,56 \%$ dari anggaran, triwulan II sebesar 20,11\%, triwulan III sebesar $18,75 \%$ dan triwulan IV sebesar $39,68 \%$. Jika dilihat perbandingan antara realisasi penyerapan belanja langsung dan belanja tidak langsung, realisasi belanja tidak langsung lebih tinggi daripada belanja langsung. Realisasi belanja tidak langsung triwulanan berkisar antara $11,16 \%$ sampai $37,60 \%$ sementara realisasi belanja langsung triwulanan berkisar antara 2,73\% sampai dengan $42,74 \%$.

\section{Efisiensi dan Efektifitas Belanja}

Nilai efisiensi belanja daerah diperoleh dengan metode data envelopment analysis (DEA) dengan orientasi peningkatan output yakni melihat efisiensi sebagai peningkatan output secara porposional dengan menggunakan tingkat input yang sama (Nurul, 2012). Dalam mengukur efisiensi pada bagian ini, fokus kajian dilakukan terhadap belanja daerah periode 2013-2015. Unit ekonomi atau DMU (decision making unit) adalah Pemerintah Provinsi Banten untuk masingmasing tahun 2013,2014 dan 2015. Variabel input yang digunakan adalah realisasi belanja daerah masing-masing tahun, sedangkan variabel ouput adalah indeks pembangunan manusia (IPM), laju 
pertumbuhan ekonomi LPE, penduduk miskin serta pengganguran terbuka. Berdasarkan hasil analisis yang dilakukan dengan menggunakan aplikasi excel sederhana yang dibuat oleh Komaruddin (https://staff.blog.ui.ac.id/komarudin74/) diperoleh hasil sebagaimana disajikan pada Tabel 4.

Tabel 4. Nilai efisiensi belanja daerah 2013-2015

\begin{tabular}{|c|c|c|c|c|c|c|c|}
\hline \multirow[b]{2}{*}{ Tahun } & \multicolumn{4}{|c|}{ Output (\%) } & \multirow{2}{*}{$\begin{array}{c}\text { Input } \\
\text { (Rp-milyar) }\end{array}$} & \multicolumn{2}{|c|}{ Efisiensi } \\
\hline & IPM & LPE & $\begin{array}{l}\text { Penduduk } \\
\text { miskin }\end{array}$ & $\begin{array}{c}\text { Pengangguran } \\
\text { terbuka }\end{array}$ & & Rasio & Kriteria \\
\hline 2013 & 69,47 & 5,86 & 5,89 & 9,90 & 5.295 & $100 \%$ & Efisien \\
\hline 2014 & 69,89 & 5,47 & 5,51 & 9,07 & 6.192 & $100 \%$ & Efisien \\
\hline 2015 & 70,27 & 5,37 & 5,9 & 9,65 & 8.084 & $100 \%$ & Efisien \\
\hline
\end{tabular}

Sumber : LKPD, LAKIP Banten 2013-2015. Diolah

Berdasarkan hasil pada Tabel 4 diatas, dapat dikatakan bahwa belanja daerah tahun 2013 sampai dengan tahun 2015 sudah efisien dalam mencapai output IPM, LPE, Penduduk miskin dan pengangguran terbuka.

Efektifitas berkaitan dengan kemampuan belanja daerah untuk mencapai sasaran yang telah ditetapkan dalam rencana pembangunan daerah. Pemprov Banten dalam Laporan Akuntabilitas Kinerja Instansi Pemerintah (LAKIP) memiliki 4 Indikator Kinerja Utama (IKU) yang terdiri dari Indeks Pembangunan Manusia, Laju Pertumbuhan Ekonomi (LPE), Persentase Penduduk Miskinda dan Persentase Pengangguran Terbuka. Kriteria pengukuran capaian kinerja yang dilakukan oleh Pemerintah Provinsi Banten didasarkan pada suatu target yang telah ditetapkan dalam Penetapan Kinerja. Kriteria tersebut merupakan komitmen dari Gubernur dan Kepala SKPD untuk mencapai hasil yang diinginkan dari setiap sasaran/program dan kegiatan yang dilakukan (LAKIP, 2015).

Merujuk pada kategori efektifitas yang dinyatakan oleh Mahmudi (2010;143), (sangat efektif $(>100 \%)$, efektif $(100 \%)$, cukup efektif (90\%-99\%), kurang efektif (75\%-89\%), tidak efektif $(<75 \%)$ ), efektifitas capaian indikator kinerja utama Provinsi Banten dapat digambarkan pada Tabel 5.

Tabel 5 Capaian efektifitas IKU Provinsi Banten

\begin{tabular}{|c|c|c|c|c|c|c|}
\hline No & Sasaran Strategis dan Indikator & Tahun & Target & Realisasi & Capaian & Efektifitas \\
\hline \multirow[t]{3}{*}{1} & \multirow[t]{3}{*}{ Indeks Pembangunan Manusia } & 2013 & 73,47 & 69,47 & 95 & Cukup \\
\hline & & 2014 & 74,02 & 69,89 & 94 & Cukup \\
\hline & & 2015 & 74,57 & 70,27 & 94 & Cukup \\
\hline \multirow[t]{3}{*}{2} & \multirow[t]{3}{*}{ Laju Pertumbuhan Ekonommi } & 2013 & $6,5-6,70$ & 5,86 & 90 & Cukup \\
\hline & & 2014 & $6,65-6,80$ & 5,47 & 82 & Kurang \\
\hline & & 2015 & $6,60-6,80$ & 5,37 & 81 & Kurang \\
\hline \multirow[t]{3}{*}{3} & \multirow[t]{3}{*}{ Persentase Penduduk Miskin } & 2013 & $5,50-5,20$ & 5,89 & 88 & Kurang \\
\hline & & 2014 & $5,50-5,30$ & 5,51 & 96 & Cukup \\
\hline & & 2015 & $5,10-4,80$ & 5,9 & 81 & Kurang \\
\hline \multirow[t]{3}{*}{4} & \multirow{3}{*}{$\begin{array}{l}\text { Persentase } \\
\text { Terbuka }\end{array}$} & 2013 & 10,24 & 9,90 & 103 & Sangat \\
\hline & & 2014 & 9,74 & 9,07 & 107 & Sangat \\
\hline & & 2015 & 9,24 & 9,65 & 96 & Cukup \\
\hline
\end{tabular}

Sumber : LAKIP Prov Banten 2013-2015, diolah

Secara rata-rata tingkat efektifitas belanja daerah dalam mencapai indikator kinerja utama dalam periode 2013-2017 berada pada angka 92,5\% yang berarti belanja daerah Provinsi Banten cukup efektif pengaruhnya terhadap kepentingan publik. 


\section{Akuntabilitas dan Transparansi.}

Sebagai bentuk pertangungjawaban pengelolaan APBD, Pemerintah Provinsi Banten menyusun laporan keuangan setiap tahunnya. Laporan keuangan yang disusun, diaudit oleh BPK untuk memperoleh opini yang merupakan cerminan pengelolaan keuangan daerah. Dikaitkan dengan hasil audit BPK, hasil audit atas laporan keuangan tahun 2013 dan 2014 masih belum mencerminkan belanja yang berkualitas. Hal ini ditandai dengan opini audit BPK yaitu Tidak Memberikan Pendapat dan adanya beberapa belanja daerah yang berkaitan dengan kasus tindak pidana korupsi yang tidak dapat dipertanggungjawabkan. Hal ini menjadi pertimbangan BPK dalam memberikan opini. Tahun 2015, kualitas belanja daerah Provinsi Banten dari sisi hasil audit BPK mengalami kemajuan ditandai dengan meningkatnya opini audit yang diperoleh menjadi Wajar Dengan Pengecualian (WDP). Untuk laporan keuangan tahun 2016, sampai penelitian lapangan dilaksanakan masih dalam proses audit BPK.

Dalam hal tanggung jawab terhadap transparansi, Pemerintah Provinsi Banten telah menerbitkan Perda Provinsi Banten No 8 Tahun 2012 Tentang Tata Kelola Keterbukaan Informasi Publik Dalam Penyelenggaraan Pemerintahan Daerah. Perda ini merupakan komitmen Pemerintah Provinsi Banten dalam memberikan akses dan keterbukaan informasi pada publik. Dengan adanya kebijakan ini diharapkan dapat meningkatkan sistem pengawasan kinerja pemerintah dalam pengelolaan belanja daerah. Menggunakan website http://bantenprov.go.id/ Pemprov Banten menyediakan berbagai informasi sebagai bentuk pertanggungjawaban dan transparansi pengelolaan APBD. Atas kinerja keterbukaan informasi publik ini pata tahun 2013, Pemprov Banten memperoleh Keterbukaan Informasi Publik Award dari Pemerintah.

\section{Strategi Peningkatan Kualitas Belanja Provinsi Banten}

Analisis SWOT (Strenght,

Weakness, Opportunity, Treahth) dilakukan untuk merumuskan pemilihan strategi dalam rangka peningkatan kualitas belanja daerah Pemerintah Provinsi Banten. Ada dua faktor yang dijaring dari informan atau ahli yaitu faktor kunci internal dan faktor kunci eksternal. Faktor kunci internal akan menghasilkan dua elemen penting yaitu kekuatan dan kelemahan, sedangkan faktor kunci eksternal akan menghasilkan peluang dan ancaman. Berdasarkan hasil pengolahan data kuesioner terhadap faktor internal dan eksternal serta rumusan kombinasi faktor internal dan eksternal diperoleh alternatif strategi sebagaimana disajikan pada Tabel 6.

\section{Perumusan Strategi Prioritas melalui Quantitative Strategic Planning Matrix (QSPM)}

Penentuan strategi prioritas dilakukan dengan menetapkan tingkat ketertarikan relatif (relative attractivenes) dari beberapa alternatif strategi dengan menggunakan skor daya Tarik yang terdiri dari (1) tidak ada daya Tarik; (2) daya tarik rendah; (3) daya tarik sedang dan (4) daya tarik tinggi. Hasil dari skor daya tarik akan mengasilkan Skor Daya Tarik Total (Total Attractiveness Score-TAS) yang merupakan nilai keseluruhan daya tarik total yang menunjukkan strategi yang utama untuk diimplementasikan. Berdasarkan hasil QSPM, strategi prioritas yang akan diimplementasikan adalah Peningkatan komitmen seluruh pihak yang berada dalam lingkungan Provinsi Banten untuk bersama-sama meningkatkan kualitas belanja daerah dengan nilai skor 6.11. 


\section{Tabel 6. Matriks SWOT dan Alternatif Strategi Peningkatan Kualitas Belanja}

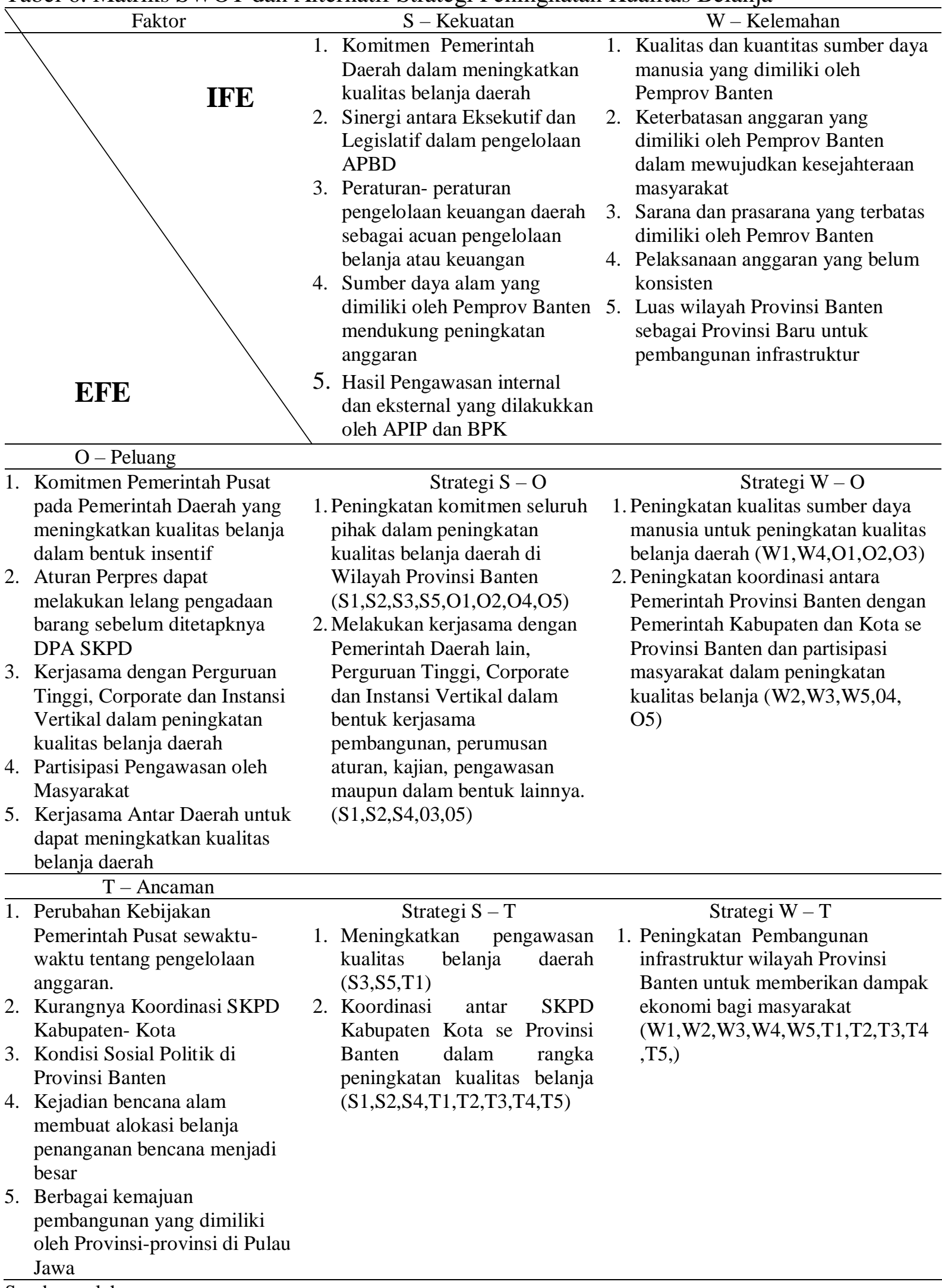

Sumber : olahan

\section{Perancangan Program}

Sebagai tindak lanjut dari rumusan strategi utama yang sudah diperoleh dari analisis QSPM adalah implementasi dari strategi prioritas tersebut. Untuk dapat mengimplementasikan strategi tersebut, disusun suatu kebijakan operasional sebagai pedoman atau acuan pelaksanaan 
strategi. Kebijakan operasional memberikan arahan program dan kegiatan yang akan dilakukan untuk mencapai sasaran yang telah ditetapkan. Program dan kegiatan yang direncanakan untuk dilaksanakan yaitu program peningkatan pengelolaan keuangan daerah dengan kegiatan peningkatan pengelolaan keuangan daerah dalam bentuk penandatanganan komitmen peningkatan kualitas belanja daerah dan sosialisasi tentang belanja berkualitas. Pelaksanaan kegiatan ini nantinya menjadi tanggung jawab Badan Pengelola Keuangan dan Aset Daerah (BPKAD) Provinsi Banten.

\section{SIMPULAN DAN SARAN}

\section{Simpulan}

Berdasarkan temuan dan hasil pembahasan sebelumnya, dapat ditarik kesimpulan sebagai berikut :

1) Anggaran dan realisasi APBD Provinsi Banten periode tahun 2013-2017 belum menunjukkan keberpihakan yang tinggi pada pelayanan publik. Hal ini ditandai dengan tingginya alokasi belanja tidak langsung dibandingkan belanja langsung. Rendahnya alokasi belanja modal sebagai belanja yang berkaitan dengna kepentingan publik juga menandai belum berpihaknya ABPD pada kepentingan publik. Dari sisi realisasi, belanja tidak langsung lebih tinggi dibandingkan dengan belanja langsung. Begitu juga halnya dengan belanja modal sebagai belanja yang digunakan untuk kepentingan publik memiliki realisasi belanja yang rendah dibandingkan dengan belanja-belanja lainnya.

2) Secara garis besar belanja daerah Provinsi Banten relatif belum berkualitas. Beberapa variable dan indikator kualitas belanja sudah menunjukkan hasil yang baik dan beberapa variabel dan indikator masih menunjukkan hasil yang masih kurang baik. a) Belanja daerah sudah sejalan dengan program prioritas yang telah ditetapkan dalam RPJMD.

b) Alokasi belanja modal Provinsi Banten periode 2013-2017 belum mencapai $30 \%$ dan cenderung mengalami penurunan. Realisasi belanja modal masih sangat rendah dibanding belanja lainnya. Alokasi belanja pegawai cukup baik. Belanja hibah dan bantuan sosial relatif belum tepat sasaran. Pengelolaan belanja hibah dan bansos belum menggambarkan tujuan diberikannya hibah dan bansos dalam mendukung pencapaian sasaran pemerintah daerah.

c) Pemerintah Provinsi Banten menetapkan APBD secara tepat waktu sebanyak 3 kali dan terlambat 2 kali yaitu tahun 2014 dan 2017 dalam periode 2013-2017. Dalam periode tersebut pendapatan dapat direalisasikan secara tepat waktu namun belanja daerah tidak bisa direaliasi secara tepat waktu.

d) Hasil evaluasi efisiensi menunjukkan bahwa belanja Provinsi Banten sudah efisien. Efektif belanja daerah belum menunjukkan tingkat yang efektif karena belum tercapainya sasaran capaian yang sudah ditetapkan.

e) Secara akuntabilitas, pertanggung jawaban pengelolaan keuangan terus meningkat ditandai dengan opini Wajar Tanpa Pengecualian yang diperoleh Pemprov Banten pada LKPD tahun 2016. Dari sisi transparansi, Pemprov Banten sudah cukup transparan dalam menyampaikan kinerja keuangan maupun kinerja non keuangan baik lewat Laporanb Keuangan Pemerintah Daerah (LKPD), Laporan Kinerja Instansi Pemerintah Daerah (LAKIP) maupun kemudahan akses lewat internet. 
3) Stategi utama yang harus dilakukan oleh Pemerintah Daerah Provinsi Banten untuk meningkatkan kualitas belanja daerahnya adalah dengan menekankan pentingnya komitmen seluruh pihak baik jajaran Pemerintah Daerah (Eksekutif) maupun Legislatif.

\section{Saran}

1) Pemerintah Provinsi Banten harus meningkatkan kualitas pengelolaan belanja daerah, dilakukan dengan fokus pembangunan pada program-program yang menjadi prioritas pemerintah daerah. Koordinasi antara pemerintah daerah kabupaten kota dan pemerintah provinsi harus ditingkatkan agar apa yang menjadi prioritas daerah dapat diwujudkan. Pemerintah daerah harus meningkatkan alokasi belanja yang lebih besar lagi bagi kepentingan publik serta meningkatkan kemampuan merealisasikan belanja tersebut dalam rangka pembangunan kepentingan publik. Ketepatan sasaran pemberian hibah dan bansos harus menjadi perhatian pemerintah daerah. Dukungan kebijakan dan aturan dalam melakukan evaluasi hibah dan bansos yang berkaitan dengan ketepatan sasaran diperlukan agar setiap evaluasi yang dilakukan terhadap proposal hibah dan bansos bukan hanya bersifat kelengkapan.

2) Pemerintah Daerah Provinsi Banten harus menekankan pentingnya komitmen seluruh pihak dalam bentuk penandatanganan pakta komitmen pengelolaan belanja daerah. Pemerintah Provinsi Banten melakukan sosialisasi tentang kualitas belanja dan indikator-indikator capain yang mendukung pengelolaan belanja yang berkualitas bagi seluruh pelaksana kegiatan dan pimpinan SKPD.

\section{DAFTAR PUSTAKA}

Bappenas. 2011. Kajian Kualitas Belanja Anggaran Pendapatan dan Belanja
Daerah (APBD). Laporan Akhir. (ID) Jakarta.2011.

Juanda et al. 2013. Evaluasi Regulasi Pengelolaan Keuangan Daerah dan Pengaruhnya Terhadap Upaya Peningkatan Kualitas Belanja Daerah. (ID). Jakarta.2013

Kemenkeu-DJPK. 2014. Laporan Pelaksanaan Spending Performance Dalam Mendanai Pelayanan Publik. Jakarta (ID). Jakarta

Kementerian Dalam Negeri. 2013. Peraturan Menteri Dalam Negeri No 27 Tahun 2013. Pedoman Penyusunan APBD Tahun Anggaran 2014. Jakarta

Mahmudi. 2010. Analisis Laporan Keuangan Pemerintah Daerah. (ID) UPP STIM YKPN.

Meldayeni. 2011. Analisis Konsistensi Perencanaan Dan Penganggaran Bidang Kesehatan Di Kota Solok Tahun 2007-2010. Universitas Andalas.Padang.

Pemerintah Republik Indonesia. 2010. Peraturan Presiden No 5 Tahun 2010. (ID) Jakarta.

Pemerintah Provinsi Banten. 2017. Rencana Pemerintah Jangka Menengah Daerah 2012-2017. (ID) Serang.

2017.

Anggaran Pendapatan dan Belanja Daerah Tahun 2013-2017. (ID) Serang.

2017.

Laporan Keuangan Pemerintah Daerah (LKPD) Provinsi Banten Tahun Anggaran 2013-2017. (ID) Serang.

2017.

Laporan Kinerja Akuntabilitas Instansi Pemerintah (LAKIP) Daerah Tahun Anggaran 2013-2015. (ID) Serang.

www.kemenkeu-djpk.go.id diakses tanggal 25 Januari 2017

https://staff.blog.ui.ac.id/komarudin74/ diakses tanggal 12 Juni 2017 